\title{
Whole-lake food-web manipulation as a means to study community interactions in a small ecosystem
}

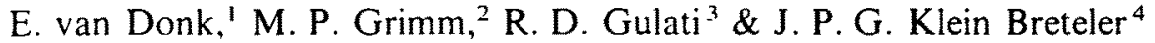 \\ 'Provincial Waterboard of Utrecht, P.O. Box 80300, 3508 TH Utrecht, The Netherlands; Present \\ address (correspondence address): Department of Nature Conservation, Aquatic Ecology Section, \\ Agricultural University, P.O. Box 8080,6700 DD Wageningen, The Netherlands; ${ }^{2}$ Witteveen \& Bos, \\ Consulting Engineers, P.O. Box 233, 7400 AE Deventer, The Netherlands; ${ }^{3}$ Limnological Institute, \\ 'Vijverhof' laboratory, Rijksstraatweg 6,3631 AC Nieuwersluis, The Netherlands; ${ }^{4}$ Organization for \\ Improvement of the Inland Fisheries, P.O. Box 433, 3430 AK Nieuwegein, The Netherlands
}

Key words: biomanipulation, whole-lake experiments, lake restoration, food-web, phytoplankton, zooplankton, Lake Zwemlust

\begin{abstract}
Whole-lake food-web manipulation was carried out in the hypertrophic Lake Zwemlust (The Netherlands), with the aim of studying the effects on the lake's trophic status and to gain an insight into complex interactions among lake communities. Before manipulation this small $(1.5 \mathrm{ha})$ and shallow $(1.5 \mathrm{~m})$ lake was characterized by Microcystis blooms in summer and high chlorophyll- $a$ concentrations were common ( $\mathrm{ca} .250 \mu \mathrm{g} \mathrm{l}^{-1}$ ). In March 1987 the planktivorous and benthivorous fish species in the lake were completely removed ( $c a .1000 \mathrm{~kg} \mathrm{ha}^{-1}$ ), a new simple fish community (pike and rudd) was introduced and artificial refuges were created. The effects of this manipulation on the light climate, nutrient concentrations, phytoplankton, zooplankton, fish, macrophytes, and macrofauna were monitored during 1987, 1988 and 1989. Community interactions were investigated in phytoplankton bioassays and zooplankton grazing experiments. After the manipulation, despite the still high $\mathbf{P}$ and $\mathbf{N}$ loads to the lake (ca. $2.2 \mathrm{~g} \mathrm{P} \mathrm{m}^{-2} \mathrm{y}^{-1}$ and $c a .5 .3 \mathrm{~g} \mathrm{~N} \mathrm{~m}^{-2} \mathrm{y}^{1}$ ), the phytoplankton density was low (Chl- $a<5 \mu \mathrm{g}$ $1^{-1}$ ), due to control by large-sized zooplankton in spring and $\mathrm{N}$-limitation in summer and autumn. A marked increase in the abundance of macrophytes and filamentous green algae in 1988 and 1989, as well as $\mathrm{N}$ loss due to denitrification, contributed to the $\mathrm{N}$ limitation of the phytoplankton. Before manipulation no submerged macro-vegetation was present but in 1988, the second year after manipulation, about $50 \%$ of the lake bottom was covered by macrophytes increasing to $80 \%$ in 1989 . This led to substantial accumulation of both $\mathrm{N}$ and $\mathrm{P}$, namely $76 \%$ and $73 \%$ respectively of the total nutrients in the lake in particulate matter. Undesirable features of the increase in macrophytes were: 1) direct nuisance to swimmers; and, 2) the large scale development of snails, especially $L$. peregra, which may harbour the parasite causing 'swimmers' itch'. But harvesting of only about $3 \%$ of the total macrophyte biomass from the swimmers' area, twice a year, reduced the nuisance for swimmers without adversely affecting the water clarity.
\end{abstract}




\section{Introduction}

In the Netherlands, eutrophication of lakes has led to massive phytoplankton growth, resulting in a virtual disappearance of most of the submerged macrophytes as well as disturbance of the food chain (Gulati \& Van Donk, 1989; Hosper, 1989). Until recently eutrophication problems were being primarily tackled by reducing external nutrient loading (Hosper \& Meijer, 1986; Van Liere, 1986). Improvement of water quality, however, seems to be retarded by the present structure of the food chain, i.e. abundance of planktivorous fish, especially bream Abramis brama (Lammens, 1989; Grimm, 1989). Whole-lake food-web manipulation by fish-stock management, i.e. reduction of the planktivorous fish, but an increase of the piscivorous fish, may accelerate the rate of the restoration process (e.g. Shapiro \& Wright, 1984; Edmondson \& Abella, 1988).

For studying the effect of food-web manipulation on lake restoration and to examine the fundamental mechanisms underlying ecosystem regulation, application of whole-lake manipulation-experiments can have major advantages. These experiments stimulate or actually encompass the conditions that would be expected to occur naturally in lakes (Carpenter \& Kitchell, 1988). Problems of enclosure-size of missing members of communities are not relevant to whole-lake manipulations (Frost et al., 1988). It is, however, difficult to perform these manipulations on a large scale and to interpret their results (Hurlbert, 1984). Interpretations may be greatly eased by results of small-scale manipulations on similar systems (Frost et al., 1988). These manipulations, however, may only provide insights into community processes if at the same time small-scale in situ or laboratory experiments, which can be replicated under controlled conditions, are executed. In this approach whole-lake manipulations can be considered as generating as well as testing hypothesis (O'Neill et al., 1986).

In 1987 the Provincial Waterboard of Utrecht started with a whole-lake food-web manipulation experiment on a small scale in the hypertrophic Lake Zwemlust, accompanied by laboratory experiments.
The biomanipulation study on Lake Zwemlust during 1987 and 1988, as well as baseline information of the year (1986) before, was presented elsewhere (Van Donk et al., 1989). Here, we attempt to present an integral picture of the 4-year study (1986-1989), with special emphasis on changes in the community structures and interactions.

\section{The lake and food-web manipulation measures}

Lake Zwemlust, a hypertrophic, small (1.5 ha) and shallow (max. depth $2.5 \mathrm{~m}$; mean depth $1.5 \mathrm{~m}$ ) waterbody, is located in the Province of Utrecht, The Netherlands. The lake is used as a swimming pool in summer. It receives seepage from the polluted River Vecht running about $50 \mathrm{~m}$ from the lake. The external $P$ and $N$ loads to the lake, via seepage from the river, are estimated at ca. $2.2 \mathrm{~g} \mathrm{P} \mathrm{m}^{-2} \mathrm{y}^{-1}$, and $5.3 \mathrm{~g} \mathrm{~N} \mathrm{~m}^{-2} \mathrm{y}^{-1}$.

Because of the high nutrient loading from the river, the water quality of the lake has deteriorated in the last two decades. Cyanobacterial blooms (e.g. Microcystis) became recurrent (Secchi-disc transparency $<30 \mathrm{~cm}$ ) and submerged macrophytes disappeared. Several unsuccessful attempts at improving the water quality were made in the past (Van Donk et al., 1989).

In March 1987, the lake was emptied by pumping out the water to facilitate complete fish elimination. Planktivorous and benthivorous species which were predominant, were collected by seineand electro-fishing. The total mass of fish removed, ca. $1500 \mathrm{~kg}$, included about $75 \%$ bream Abramis brama L. measuring 10-15 cm. Detailed results of the fishing are given in Van Donk et al., (1990a). The lake, which was refilled by seepage from the River Vecht in about 3 days, was restocked with 1600 pike (Esox lucius) fingerlings $(4 \mathrm{~cm})$ and 140 adult rudd (Scardinius erithrophthalmus L.). The offspring of the rudd were expected to serve as a food source for the pike. Also daphnids (D. magna. D. hyalina, wet weight ca. $1 \mathrm{~kg}$ ), carried along with the fish, were brought into the lake. In April 1988 a new year-class of pike fingerlings was introduced. 'Seedlings' of Chara globularis Vaill., rhizomes of Nuphar lutea L. and stacks of Salix twigs were placed as refuges 
and spawning grounds for the pike as well as shelter for the zooplankton. Due to interference of the high macrophyte biomass, after the biomanipulation, with the lake's recreational use, about $3 \%$ of the macrophyte biomass was removed from the swimming area. In 1989 both at the end of June, and at the beginning of September, strips of macrophytes were mown to a height of about $10 \mathrm{~cm}$ above the sediment with the aid of a special equipped boat. The mowed plant material was removed, weighed and analysed for $\mathrm{P}$ and N. For more details of the biomanipulation measures see Van Donk et al. (1989).

\section{Methods}

The entire water column was sampled in one stretch with a transparent, perspex tube of $1.5 \mathrm{~m}$ length and $5 \mathrm{~cm}$ diameter. In 1986, i.e. prior to the biomanipulation, the lake was sampled fortnightly between May and September at one station located in the deepest part. In 1987 and 1988 the samples were taken at ten stations and mixed. This composite sample was subsampled for the analyses of nutrients (nitrate, nitrite, ammonium and orthophosphate), total phosphate, chlorophyll-a, phytoplankton, and zooplankton. Temperature, conductivity, $\mathrm{pH}$, oxygen concentration, and Secchi disk transparency were measured in situ. Methods for analysing water chemistry and biology (phytoplankton, zooplankton, macrofauna, macrophytes, fish) are described in Van Donk et al. (1989). The role of physical factors, nutrient availability, and zooplankton grazing in structuring the composition and abundance of the natural phytoplankton populations, was investigated in laboratory experiments under controlled conditions. Growth limitation of phytoplankton in the lake was examined using natural community-enrichment bioassays during 6 days at the in situ temperature and the natural light-dark cycle. Eight one-litre Pyrex flasks were filled with lake water, filtered through $100 \mu \mathrm{m}$ gauze to remove most of the crustacean zooplankton. Two other flasks were filled with unfiltered lake water to analyse the effect of zooplankton grazing. The five treatments, performed in duplicate were: 1) filtered lake water without nutrient addition, [Control]; 2) unfiltred lake water without nutrient addition, [+Zoopl.]; 3) addition of $\mathrm{N}\left(\mathrm{NO}_{3}\right.$ $0.56 \mathrm{mg} \mathrm{N}^{-1}$ and $\left.\mathrm{NH}_{4} 0.3 \mathrm{mg} \mathrm{N}^{-1}\right),[+\mathrm{N}]$; 4) addition of $\mathrm{P}\left(0.32 \mathrm{mg} \mathrm{P} \mathrm{l}^{-1}\right),[+\mathrm{P}]$; 5) addition of 'complete freshwater medium', [Total] (Guillard, 1975). Chlorophyll-a concentration and phytoplankton density were determined daily using a Coulter Counter ( $70 \mu \mathrm{m}$ orifice tube). Phytoplankton growth was measured for 6 days, counting the cell numbers in triplicate. Because the growth response to nutrient enrichment may be delayed (lag-period), response to the nutrient enrichment was studied over the exponential phase of the growth curves only (Van Donk et al., $1988)$. Mean growth rates $(\bar{\mu})$ with the $95 \%$ confidence intervals were calculated by a least squares linear regression analysis of log-transformed data with more than one value of $Y$ per each value of $X$ (Sokal \& Rohlf, 1969).

Zooplankton grazing and assimilation rates of the crustacean zooplankton were measured weekly or fortnighly in the laboratory, employing the ${ }^{14} \mathrm{C}$-tracer technique (Gulati et al., 1982), using lake seston $(<33 \mu \mathrm{m})$ as tracer food. The biomass of seston food $(<33 \mu \mathrm{m})$ and zooplankton $(>150 \mu \mathrm{m})$ were measured by the COD technique (Goldman, 1969) with some modifications (Gulati et al., 1982); the oxygen consumed was converted to carbon according to Winberg et al. (1971). This conversion facilitates comparison with phytoplankton primary production, which was measured using the ${ }^{14} \mathrm{C}$-technique (Van Liere etal., 1986) from 24 June 1987 onwards.

\section{Results}

Salient features of the lake's limnology are described for each year of the study period 1986-1989.

\section{6}

In 1986 , i.e. the year before the food-web manipulation, chlorophyll- $a$ concentrations (ca. $250 \mu \mathrm{g}$ 
$\left.\mathrm{1}^{-1}\right)$ were high, caused mainly by the cyanobacterium Microcystis aeruginosa (Figs 1 and 2).

The bioassays, performed in August 1986, did not show significant change in growth rates compared with the control (Table 1). Because both $\mathrm{P}$ and $\mathrm{N}$ concentrations of the lake water were high (Figs 3 and 4), the growth of the phytoplankton community was most probably mainly limited by light. Grazing mortality was apparently low, since only small-sized zooplankters (e.g. rotifers) were present. Submerged macrophytes were absent and planktivorous fish and benthivorous fish abundant (ca. $1000 \mathrm{~kg} \mathrm{ha}^{-1}$ ).
1987

Shortly after the fish removal in March 1987 (see Van Donk et al., 1990a), there was a bloom of nano-phytoplankton taxa (Pteromonas, Cryptomonas and Nitzschia), which contributed to a chlorophyll peak of ca. $50 \mu \mathrm{g} \mathrm{Chl-a)} \mathrm{'} \mathrm{(Figs} 1$ and 2). In summer, however, chlorophyll- $a$ concentrations declined to about $5 \mu \mathrm{g} \mathrm{l}^{-1}$ and only Chlamydomonas sp., Scenedesmus sp. and some $\mu$-algae were important.

The nutrient concentrations were still high: in July the maximum of SRP was $1.6 \mathrm{mg} \mathrm{P1-1}$ and

Table 1 . The mean net growth rates $\left(\bar{\mu} \cdot\right.$ day $\left.{ }^{-1}\right)$ of the phytoplankton community of lake Zwemlust in the bioassays for the different combinations. Control, zooplankton removed (C); zooplankton not removed, no nutrient additions ( $+Z$ Zoopl.); added $\mathrm{NO}_{3} 0.56 \mathrm{mg} \mathrm{N} \cdot 1^{-1}$ and $\mathrm{NH}_{4} 0.30 \mathrm{mg} \mathrm{Nl^{-1 }}(+\mathrm{N})$; added $\mathrm{PO}_{4} 0.32 \mathrm{mg} \mathrm{Pl} \mathrm{I}^{-1}(+\mathrm{P})$; addition of complete freshwater medium (Total). The $95 \%$ confidence intervals are given in parentheses.

\begin{tabular}{lllllll}
\hline Date & $\begin{array}{l}\text { Water } \\
\text { temp. } \\
\left({ }^{\circ} \mathrm{C}\right)\end{array}$ & \multicolumn{2}{l}{ Mean growth rate $\left(\bar{\mu}\right.$ day $\left.{ }^{-1}\right)$} & & \\
\cline { 3 - 7 } & & Control & + Zoopl. & $+\mathrm{N}$ & $+\mathrm{P}$ & Total \\
\hline $1986-08-07$ & 18 & $0.08(0.03)$ & $0.10(0.05)$ & $0.10(0.06)$ & $0.07(0.07)$ & $0.11(0.05)$ \\
$1987-06-01$ & 16 & $0.30(0.05)$ & $0.08(0.06)$ & $0.33(0.06)$ & $0.30(0.06)$ & $0.35(0.04)$ \\
$1988-06-01$ & 16 & $0.12(0.05)$ & $0.04(0.06)$ & $0.37(0.05)$ & $0.14(0.03)$ & $0.39(0.07)$ \\
$1988-08-26$ & 18 & $0.21(0.10)$ & $0.09(0.03)$ & $0.34(0.10)$ & $0.15(0.07)$ & $0.38(0.05)$ \\
$1989-02-27$ & 6 & $0.12(0.07)$ & $0.09(0.04)$ & $0.14(0.08)$ & $0.25(0.11)$ & $0.16(0.07)$ \\
$1989-04-20$ & 10 & $0.47(0.06)$ & $0.44(0.04)$ & $0.70(0.09)$ & $0.44(0.05)$ & $0.84(0.11)$ \\
$1989-05-10$ & 17 & $0.28(0.04)$ & $0.14(0.04)$ & $0.41(0.07)$ & $0.28(0.03)$ & $0.45(0.06)$ \\
$1989-07-28$ & 22 & $0.06(0.02)$ & $0.08(0.02)$ & $0.22(0.04)$ & $0.11(0.05)$ & $0.35(0.09)$ \\
$1989-09-14$ & 18 & $0.11(0.04)$ & $0.09(0.03)$ & $0.30(0.05)$ & $0.16(0.04)$ & $0.39(0.08)$ \\
\hline
\end{tabular}

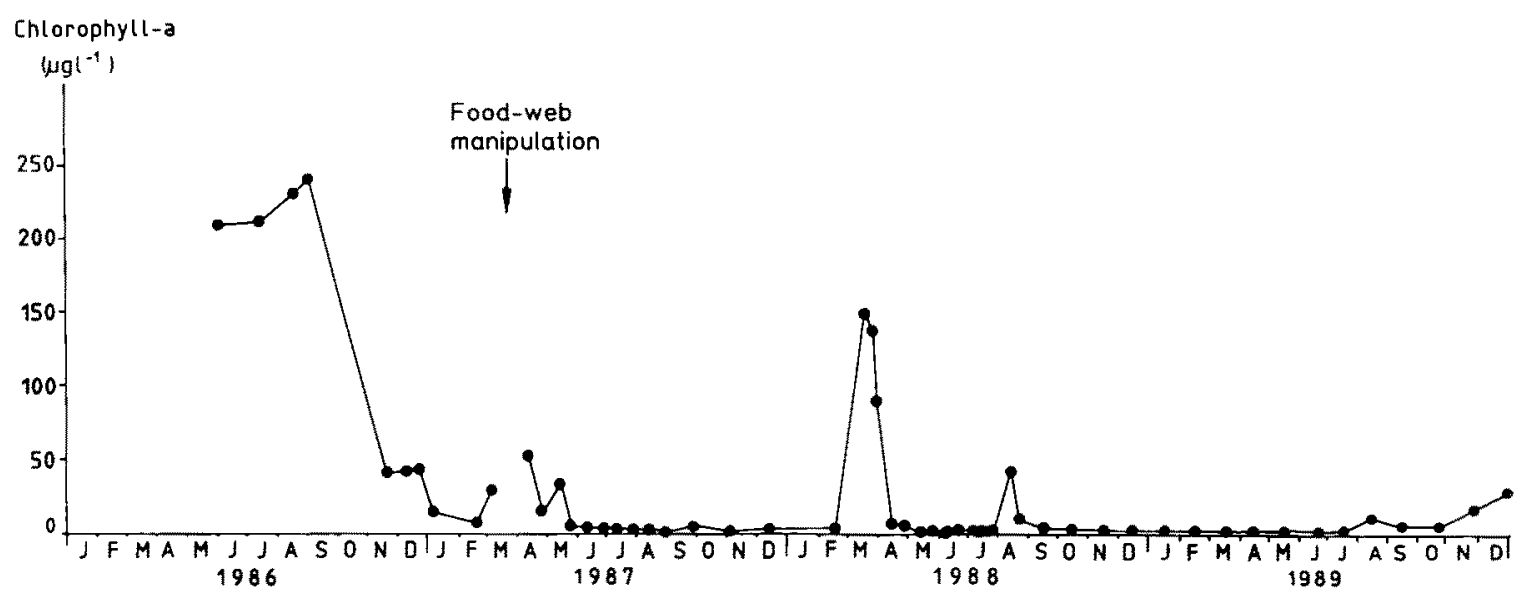

Fig. 1. Chlorophyll-a concentrations in Lake Zwemlust before and after food-web manipulation. 
Table 2. Primary production, grazing and consumption rates of the phytoplankton and crustacean zooplankton community and other relevant data from Lake Zwemlust in 1987 and 1988. S, Seston food (mg C.1 ${ }^{-1}$ ); Z, Zooplankton biomass (mg C. $\mathrm{I}^{-1}$ ); PP, Primary production (mg $\left.\mathrm{C} \cdot \mathrm{I}^{-1} \cdot \mathrm{d}^{-1}\right) ; \mathrm{G}$, grazing $\left(\% \mathrm{~d}^{-1}\right) ; \mathrm{C}$, consumption (mg $\left.C \cdot 1^{-1} \cdot d^{-1}\right)$.

\begin{tabular}{|c|c|c|c|c|c|c|}
\hline Date & $\mathrm{T}^{\circ} \mathrm{C}$ & $\mathrm{S}$ & $Z$ & PP & G & $\mathrm{C}$ \\
\hline $87-05-15$ & 13 & 1.91 & 0.62 & - & 73 & 1.39 \\
\hline $05-25$ & 18 & 1.28 & 1.16 & - & 170 & 2.18 \\
\hline $06-03$ & 18 & 0.66 & 0.87 & - & 121 & 0.79 \\
\hline $06-10$ & 17 & 0.69 & 0.56 & - & 195 & 1.35 \\
\hline $06-17$ & 17 & 0.66 & 0.48 & - & 55 & 0.36 \\
\hline $06-24$ & 17 & 0.62 & 0.32 & 0.35 & 80 & 0.50 \\
\hline $07-01$ & 21 & 0.70 & 0.66 & - & 112 & 0.78 \\
\hline $07-08$ & 24 & 0.75 & 0.34 & - & 65 & 0.49 \\
\hline $07-22$ & 21 & 0.68 & 0.32 & 0.07 & - & - \\
\hline $08-05$ & 18 & 0.71 & 0.20 & 0.09 & - & - \\
\hline $08-19$ & 21 & 0.52 & 0.22 & 0.07 & 14 & 0.08 \\
\hline $09-02$ & 20 & 0.63 & 0.30 & 0.20 & 46 & 0.29 \\
\hline $09-16$ & 18 & 0.45 & 0.28 & 0.03 & 33 & 0.15 \\
\hline $09-30$ & 14 & 0.25 & 0.28 & 0.04 & 226 & 0.58 \\
\hline $10-14$ & 11 & 0.27 & 0.15 & 0.01 & 125 & 0.34 \\
\hline $10-28$ & 10 & 0.10 & 0.16 & 0.02 & $486^{2}$ & 0.49 \\
\hline $11-11$ & 8 & 0.24 & 0.18 & 0.01 & 22 & 0.05 \\
\hline $11-25$ & 6 & 0.25 & 0.23 & - & 24 & 0.06 \\
\hline $12-22$ & 7 & - & - & 0.01 & 22 & - \\
\hline $88-03-16$ & 5 & 8.11 & 0.41 & 1.50 & 4 & 0.32 \\
\hline $04-13$ & 10 & 1.30 & 2.44 & 0.43 & 441 & 5.73 \\
\hline $04-27$ & 13 & 0.75 & 0.33 & 0.17 & 13 & 0.10 \\
\hline $05-11$ & 16 & 0.26 & 0.36 & 0.08 & 68 & 0.18 \\
\hline $05-25$ & 19 & 0.62 & 0.56 & 0.19 & 103 & 0.64 \\
\hline $05-31$ & 17 & 0.35 & 0.54 & - & 176 & 0.61 \\
\hline $06-08$ & 17 & 0.57 & 0.53 & 0.07 & 84 & 0.47 \\
\hline $06-22$ & 20 & 0.49 & 0.27 & 0.18 & 82 & 0.40 \\
\hline $07-06$ & 18 & 0.48 & 0.25 & 0.10 & 48 & 0.23 \\
\hline $07-20$ & 17 & 0.57 & 0.13 & 0.12 & 6 & 0.03 \\
\hline $08-03$ & 20 & 0.43 & - & 0.91 & 22 & 0.32 \\
\hline $08-17$ & 21 & 0.69 & 0.13 & 0.57 & 22 & 0.15 \\
\hline $08-31$ & 18 & 0.68 & 0.32 & 0.17 & 80 & 0.54 \\
\hline $09-28$ & 14 & 0.76 & 0.23 & 0.06 & 22 & 0.17 \\
\hline $10-19$ & 4 & 0.88 & 0.09 & - & 2 & 0.02 \\
\hline $10-26$ & 10 & 0.67 & 0.16 & - & 4 & 0.02 \\
\hline $89-01-25$ & 3 & 0.65 & 0.25 & 0.01 & 6 & 0.04 \\
\hline $02-24$ & 4 & 0.71 & 0.30 & 0.06 & 62 & 0.44 \\
\hline $03-15$ & 8 & 0.78 & 0.71 & 0.16 & 54 & 0.42 \\
\hline $04-12$ & 11 & 0.64 & 0.44 & 0.02 & 23 & 0.15 \\
\hline $04-26$ & 9 & 0.51 & 0.38 & 0 & 115 & 0.62 \\
\hline $05-10$ & 17 & 0.53 & 0.62 & 0.04 & 179 & 0.97 \\
\hline $05-24$ & 21 & 0.55 & 0.68 & 0.16 & 276 & 1.52 \\
\hline $06-07$ & 15 & 0.49 & 0.63 & 0.10 & 54 & 0.27 \\
\hline $06-21$ & 25 & 0.35 & 0.53 & 0.10 & 220 & 0.77 \\
\hline
\end{tabular}

Table 2. (continued)

\begin{tabular}{lclllll}
\hline Date & $T^{\circ} \mathrm{C}$ & $\mathrm{S}$ & $\mathrm{Z}$ & $\mathrm{PP}$ & $\mathrm{G}$ & $\mathrm{C}$ \\
\hline $07-05$ & 19 & 0.22 & 0.26 & 0.05 & 348 & 0.77 \\
$08-02$ & 18 & 0.59 & 0.17 & 0.60 & 140 & 0.83 \\
$08-30$ & 18 & 0.49 & 0.15 & 0.13 & 31 & 0.15 \\
$09-27$ & 17 & 1.58 & 0.50 & 0.20 & 45 & 0.72 \\
$10-25$ & 14 & 0.51 & 0.13 & 0.10 & 5 & 0.02 \\
$11-22$ & 4 & 0.78 & - & 0.05 & 8 & 0.06 \\
$12-20$ & 6 & 1.03 & 0.14 & - & 5 & 0.05 \\
\hline
\end{tabular}

of $\mathrm{NH}_{4} 1.6 \mathrm{mg} \mathrm{N} \mathrm{I}$ (Figs 3 and 4). In May-June large-bodied species of Daphnia (D. magna; D. hyalina) became dominant (Fig. 5); their daily grazing rates on the seston food $(<33 \mu)$ exceeded $100 \% \mathrm{~d}^{-1}$ (Table 2). Cyanobacteria were absent. In June the mean rates of phytoplankton increase were the lowest in the bioassays in which zooplankton was present ( + Zoopl.: Table 1), indicating that zooplankton grazing controlled phytoplankton growth.

Only $5 \%$ of the lake bottom was covered with macrophytes in the summer. Chara globularis, Potamogeton crispus, $P$. berchtoldii, Elodea nuttallii and $E$. canadensis formed the main vegetation. About fifty of the ca. two hundred Nuphar lutea rhizomes, planted in March 1987, flowered. In August filamentous green algae (mostly Hydrodyction reticulatum and Enteromorpha sp.), were present particularly in the littoral.

Spawning of the rudd stocked in early April 1987 was delayed to mid July, due to low spring temperatures. The $0^{+}$rudd measured only $c a$. $2.5 \mathrm{~cm}$ at the onset of the winter period; the samples taken in March 1988, indicated that survival of fish in the preceding winter was extremely low. Because of low biomass of the young rudd and scarce submerged macrophytes in 1987 , the intraspecific predation among the $0^{+}$ pike was high. The population ( $c a .300$ ind.) of $0^{+}$ pike had at the end of 1987 a biomass of $c a .26 \mathrm{~kg}$, which is far below the expected ca. $100 \mathrm{~kg}$. Only about $20 \%$ of the stocked pike survived the first year. 


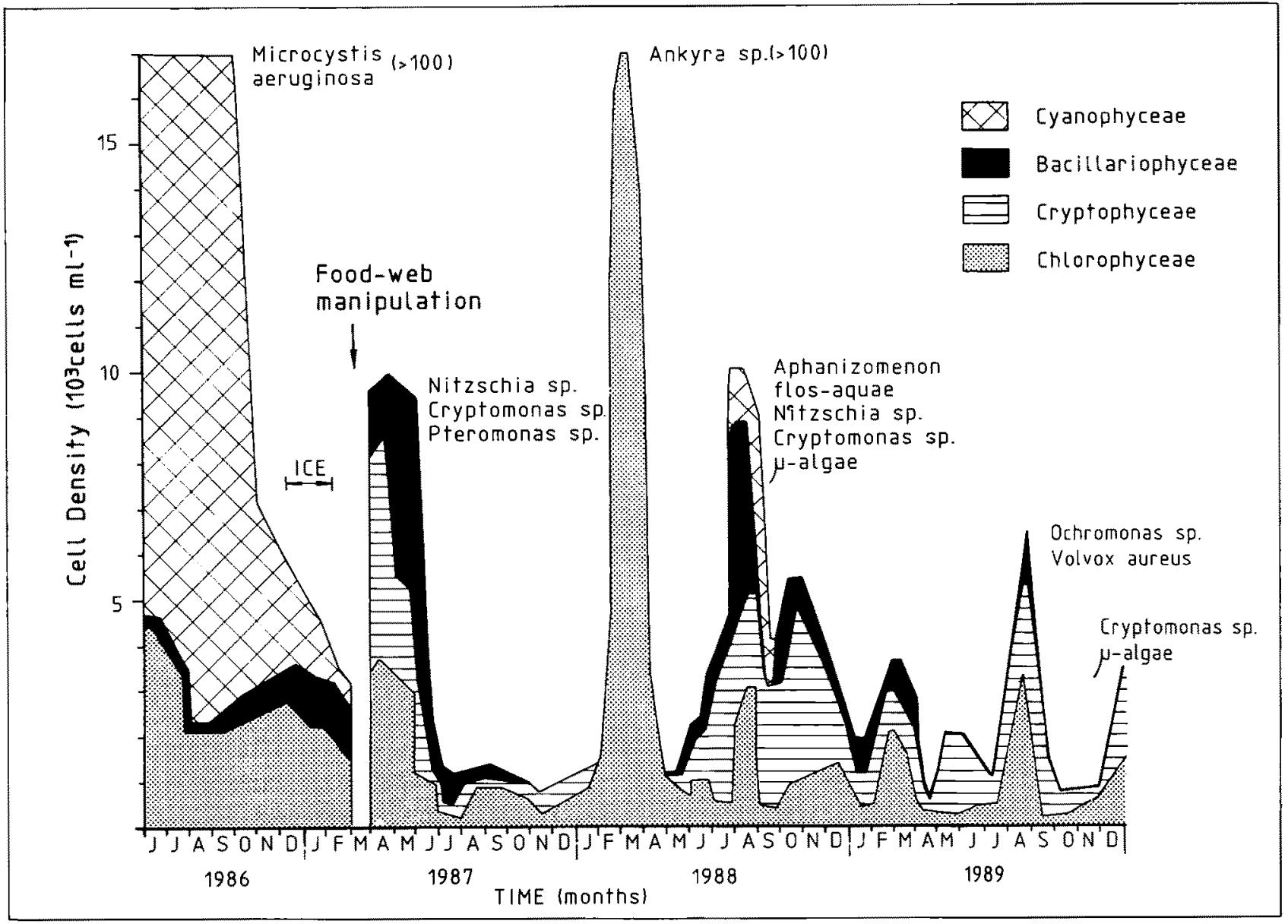

Fig. 2. Phytoplankton population dynamics in Lake Zwemlust before and after food-web manipulation.

1988

In March the chlorophyll-a concentrations reached $150 \mu \mathrm{gl}^{-1}$, due to a bloom of Ankyra sp., a chlorophyte (Figs 1 and 2). This bloom disappeared quickly after the temperature exceeded $10^{\circ} \mathrm{C}$ and Daphnia pulex reached ca. 350 ind. $\mathrm{I}^{-1}$. In the summer small-sized cryptophyceans dominated the phytoplankton. The secondary chlorophyll-a peak of $35 \mu \mathrm{g} \mathrm{I}^{-1}$ in August was caused by taxa of Cryptomonas, Nitzschia and a nitrogen-fixing cyanobacterium Aphanizomenon flos-aquae. The nitrate and ammonium concentrations declined to near detection levels in spring and remained so in summer; in contrast the $\mathrm{P}$-concentrations remained high (Figs 3 and 4). Furthermore, some algal species resistant to graz- ing by zooplankton appeared: in April Colacium sp., a euglenophyte, bloomed and it especially adhered firmly onto and completely covered D. pulex. Also large colonies of Volvox aureus were encountered in the summer of 1988; these 'inedible' species were, however, not abundant.

The rotifer, copepod and cladoceran densities were lower than in 1987. Daphnia pulex had already become dominant by April. Grazing pressure of zooplankton in spring 1988, as in spring 1987, was high and it peaked even earlier (13 April); $D$. pulex the sole efficient grazer, increased rather rapidly between mid March and mid April, even though the water temperature was still low, having increased from 5 to $10^{\circ} \mathrm{C}$ in the 4-week period (Table 2). Apparently, Ankyra sp., which developed a major bloom, formed a good food for 


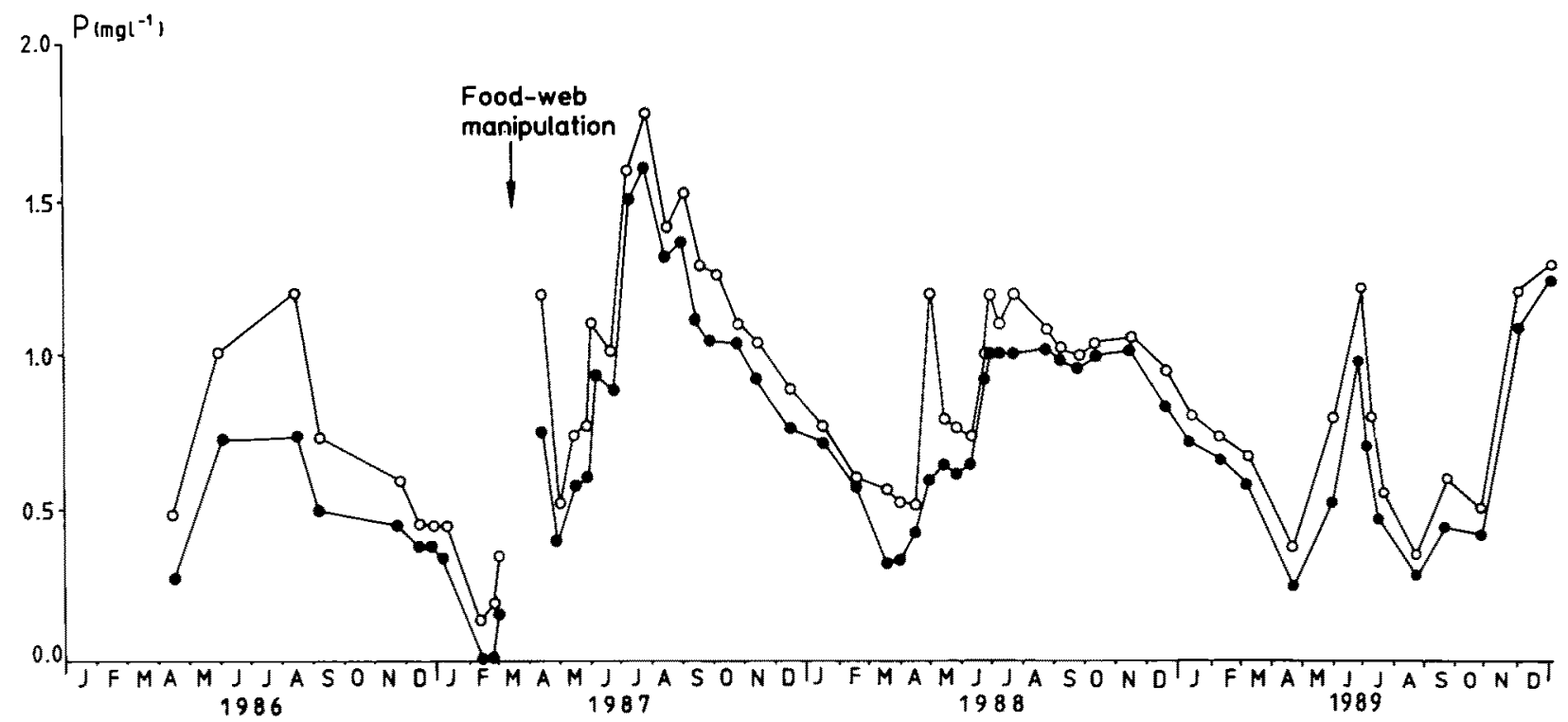

Fig. 3. The concentrations of SRP $(\bullet)$ and total-P $(0)$ in Lake Zwemlust before and after food-web manipulation.

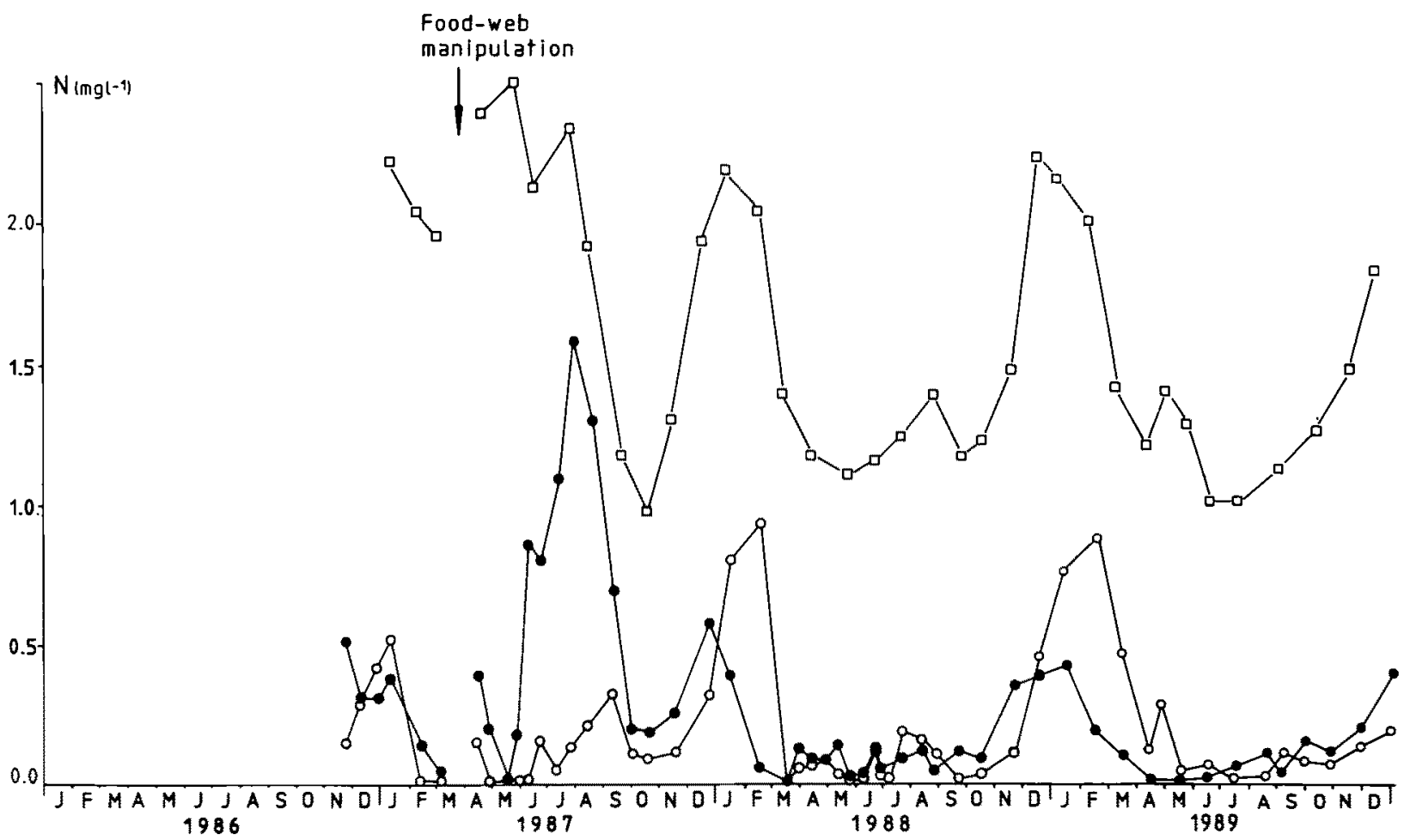

Fig. 4. The concentrations of total $\mathrm{N}(\square), \mathrm{NH}_{4}-\mathrm{N}(\bullet)$ and $\mathrm{NO}_{3}-\mathrm{N}(0)$ in Lake Zwemlust before and after food-web manipulation. 


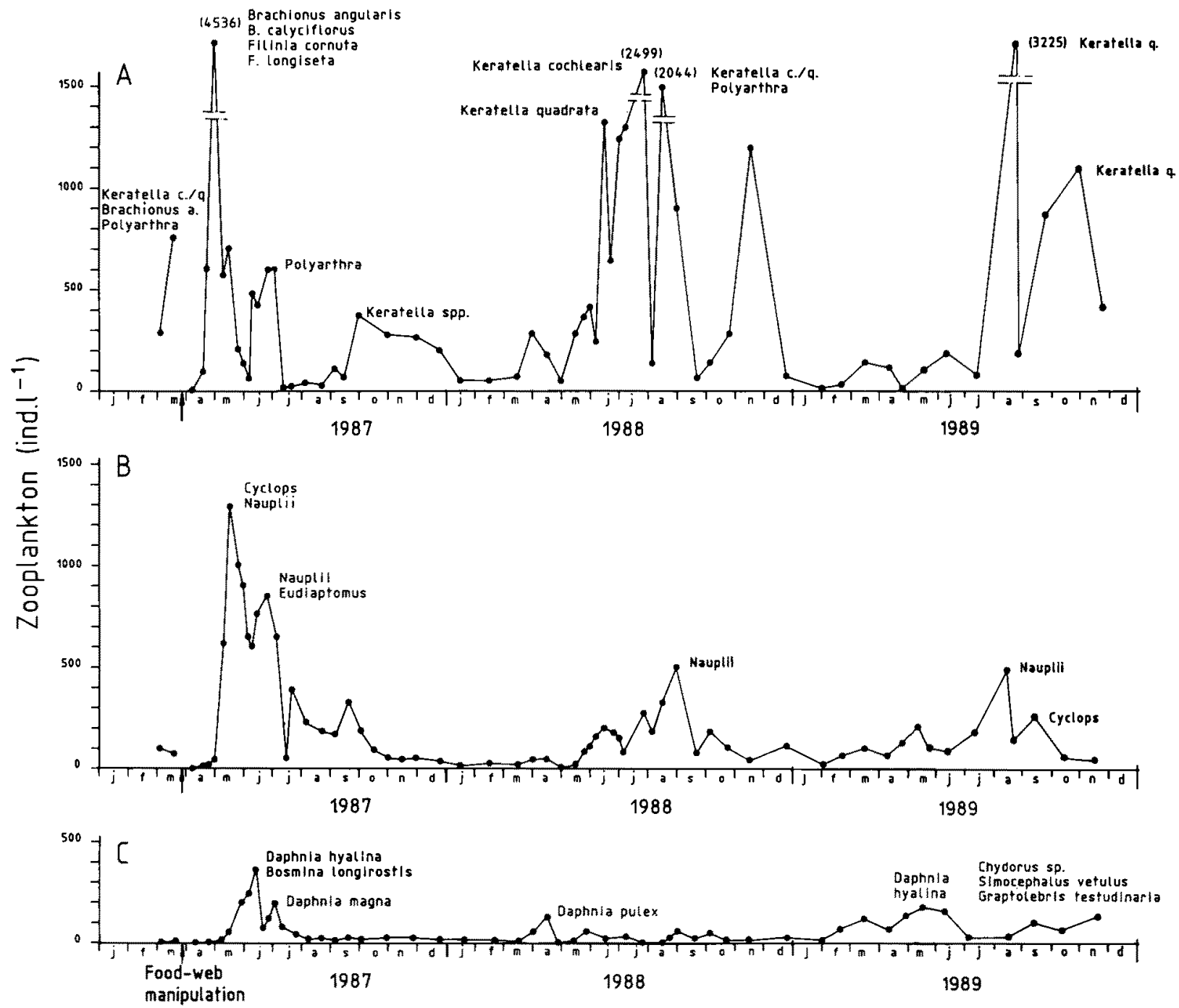

Fig. 5. The abundance of herbivorous zooplankton in Lake Zwemlust before and after food-web manipulation, Rotifers (A), Copepods (B) and Cladocerans (C). The species dominant on some of the sampling dates are indicated.

D. pulex, which contributed mainly to the more than two-orders-of-magnitude increase in the community grazing from 4 to $441 \% \cdot d^{-1}$. This increase was reflected in equally sharp and concomitant, but inverse, changes in primary production rates and seston concentrations (Table 2 ). Subsequently, the filter-feeding zooplankton declined drastically in summer. There is some evidence from the fecundity data, as well as from food quality, that the crash in zooplankton was partly related to both low food concentration and poor food quality (e.g. Volvox aureus) (Gulati,
1989). The relatively low specific assimilation rates found in this period support this contention. Also predation on large zooplankton by $0^{+}$rudd may have contributed to the crustacean decrease in summer 1988.

In June and August, 1988, net growth rates of the phytoplankton were the lowest in the bioassays in which zooplankton was not removed (+Zoopl.: Table 1). However, the growth rates in the controls and in the bioassay with $P$ enrichment were not significantly higher. Significant stimulation of the growth rate was found only 
with $\mathrm{N}$ addition $\left(\mu=0.37 \mathrm{~d}^{-1}\right.$ in June 1988 , and $0.34 \mathrm{~d}^{-1}$ in August 1988), when both nitrate and ammonium in the lake were close to detection level.

This decrease in $\mathrm{N}$ level coincided with a high standing crop (average dry weight $89 \mathrm{~g} \mathrm{~m}^{-2}$ ) of macrophytes, covering between 50 and $60 \%$ of the lake bottom during summer. About 150 Nuphar lutea plants flowered and some submerged macrophytes ( $P$. berchtoldii, $E$. nuttallii) and filamentous green algae on their emergence interfered with the recreational use of the lake (Van Donk \& Collé, 1988; Ozimek et al., 1990). Associated with the macro-vegetation and possibly with the absence of larger cyprinids (the diet of which also comprises snails), a large snail population, especially Lymnaea peregra var. ovata, developed. This species, which was most abundant on the bottom underneath the macrophytes with mean densities of 102 ind. $\mathrm{m}^{-2}$, is known to act as an intermediate host of the bird-parasitizing trematode Trichobilharzia ocellata, the cercaria of which cause an itching sensation at the spot of penetration in the human skin, accompanied by rash (schistosome dermatitis or swimmers'itch). In July about $40 \%$ of the bathers complained about this itching.

In 1988 the rudd spawned relatively late at the end of May, confronted at the beginning of the year with yearlings and $0^{+}$pike, which lacked forage fish. This and the scarcity of submerged macrophytes in early spring led again to a high intra-specific predation among the pike population. In October about $2000^{+}$pike were present compared with 300 in October 1987. The $0^{+}$pike were also smaller than in 1987 and their population biomass being $16 \mathrm{~kg}$ compared with $26 \mathrm{~kg}$ in 1987. Information on the length frequencies and conditions of the $0^{+}$and $1^{+}$pike is given in Van Donk et al. (1989). This year the rudd spawned the second time early in July, when the predation pressure on the rudd by pike was low due to intraspecific predation among the latter. The $0^{+}$ rudd were very abundant $(200000$ ind.) in August. Subsequently, their numbers were reduced to 114000 ind. in Oct. and the biomass was $74 \mathrm{~kg}$ by that time. The reduction in rudd density was caused probably by a marked decrease in crustacean zooplankton. The condition of the $0^{+}$rudd also decreased during autumn. A shift from cladoceran zooplankton to rotifers was probably caused mainly by predation of $0^{+}$rudd. The data on the gut contents of $0^{+}$rudd support this hypothesis. $1^{+}$rudd $(8-12 \mathrm{~cm})$ were only incidentally caught, their average growth being $6 \mathrm{~cm}$. The rudd stocked in $1987(9-13 \mathrm{~cm})$ ranged in length from 16 to $19 \mathrm{~cm}$ at the end of 1987 and 20 to $25 \mathrm{~cm}$ in 1988. For more information see Van Donk et al. (1989).

\section{9}

In contrast with the preceding two years, an early spring bloom of chlorophyceans was absent in 1989. The mild winter of 1988-1989 (mean water temperature $c a .6^{\circ} \mathrm{C}$ ) probably contributed to the relatively high zooplankton biomass. The total crustacean density was 140 ind. $1^{-1}$ in mid March 1989 compared with only 26 ind. $1^{-1}$ in mid March 1988. This is also reflected in the marked difference in zooplankton grazing pressure on seston $(<33 \mu \mathrm{m})$, namely $54 \% \mathrm{~d}^{-1}$ in 1989 and $4 \% \mathrm{~d}^{-1}$ in 1988 (Table 2 ).

The chlorophyll- $a$ concentrations were around detection level, but the $\mathrm{N}$ and $\mathrm{P}$ concentrations were relatively high until the beginning of April, (Figs 1, 3, 4). As in 1988 the nitrate and ammonium concentrations remained below detection limits from April to October. In contrast with the preceding years also the $\mathrm{P}$ concentrations, total $-\mathrm{P}$ as well as SRP, declined to reach their annual minimum in August: $t-P=0.41 \mathrm{mg}$ $1^{-1} ; \mathrm{SRP}=0.28 \mathrm{mg} \mathrm{l}^{-1}$ (Fig. 3). This decrease in nutrients in August coincided with a small (14 $\mu \mathrm{g}$ $1^{-1}$ ) chlorophyll- $a$ peak (Fig. 1), due mainly to Volvox aureus and the cryptophyte Ochromonas sp. (Fig. 2).

The crustacean densities were comparable with 1988, but much lower than in 1987 (Fig. 5). There was a dominance in the spring of Daphnia hyalina and of species more associated with macrophytes (Chydorus sp., Simocephalus vetulus, Graptoleberis testudinaria) in late summer and autumn. The 
latter two species were not detected using the routine sampling and counting procedures in the preceding years. This species shift is associated with enormous increase of macrophytes. The grazing pressure of the zooplankton was high during spring but, as in 1988, it declined drastically in summer after a dramatic decrease in the filterfeeding zooplankton (Table 2).

The enrichment bioassays in February 1989, did not show any significant increase in phytoplankton growth. The growth rate in the control at $6^{\circ} \mathrm{C}$ was low $\left(0.12 \mathrm{~d}^{-1}\right)$ but at $17^{\circ} \mathrm{C}$ and under optimal light conditions $(14 \mathrm{~L}-10 \mathrm{D}$; 30 Watt $\mathrm{m}^{-2}$ ) it increased more than three-fold. The study showed that temperature and light mainly controlled phytoplankton growth in February 1989. The bioassays in May indicated a significant adverse effect of zooplankton grazing on phytoplankton growth; main grazers were the large-bodied Daphnia species (ca. 140 ind. $1^{-1}$ ). The phytoplankton growth rates significantly increased after $\mathrm{N}$ additions from April onwards, when nitrate and ammonium in the lake were close to detection level. Most probably the phytoplankton community was $\mathrm{N}$ limited.

Due to the relatively mild winter a large part of the lake was covered with macrophytes already early in spring; this contributed to the $\mathrm{N}$ limitation of the phytoplankton. Submerged macrophytes covered in summer roughly $80 \%$ of the lake bottom compared with only $5 \%$ in 1987 and $50 \%$ in 1988 , the changes in the submerged vegetation during 1988 and 1989 were only quantitative. E. nuttallii comprised in $198975-85 \%$ of the total standing crop of submerged macrophytes. For more detailed information on the species composition see Ozimek et al. (1990).

Comparing the amounts of $\mathrm{N}$ and $\mathrm{P}$ in the different compartments of the lake's ecosystem before and after food-web manipulation, in 1989 nearly three quarters of both total $\mathrm{N}$ and total $\mathrm{P}$ in the lake was stored in submerged macrophytes (Table 3). In contrast, in 1986, i.e. before the manipulation, phytoplankton contained about $45 \%$ of both total $\mathrm{N}$ and total $\mathrm{P}$. The high standing crop of macrophytes through the entire water column interfered with the lake's recreational use. Both at the end of June and beginning of September about $3 \%$ of total macrophyte biomass in the lake was removed from the swimming area. The mowing possibly also prevented the occurrence of swimmers' itch. The densities of

Table 3. The amounts of phosphorus and nitrogen in kg distributed over the different compartments of the ecosystem of Lake Zwemlust before (1986) and after biomanipulation (1987, 1988 and 1989).

\begin{tabular}{|c|c|c|c|c|c|c|c|c|}
\hline \multirow[b]{2}{*}{$(\mathrm{kg})$} & \multicolumn{2}{|c|}{ Aug. 1986} & \multicolumn{2}{|c|}{ Aug. 1987} & \multicolumn{2}{|c|}{ Aug. 1988} & \multicolumn{2}{|c|}{ Aug. 1989} \\
\hline & $N$ & $P$ & $N$ & $P$ & $\mathrm{~N}$ & $\mathrm{P}$ & $N$ & $\mathrm{P}$ \\
\hline SRP & - & 15 & - & 36 & - & 22 & - & 9 \\
\hline $\mathrm{NH}_{4}-\mathrm{N}$ & 11 & - & 31 & - & 2.5 & - & 0.2 & - \\
\hline $\mathrm{NO}_{3}-\mathrm{N}$ & 7 & - & 7 & - & 0.5 & - & 0.3 & - \\
\hline $\operatorname{org} \mathrm{N}$ & 3 & - & 16 & - & 22 & - & 19 & - \\
\hline $\begin{array}{l}\text { seston }<150 \mu \mathrm{m} \\
\text { (phytoplankton) }\end{array}$ & 40 & 16 & 5 & 1.7 & 4 & 0.9 & 2 & 0.6 \\
\hline $\begin{array}{l}\text { seston }>150 \mu \mathrm{m} \\
\text { (zooplankton) }\end{array}$ & 0.5 & 0.1 & 1 & 0.2 & 1 & 0.2 & 1 & 0.2 \\
\hline macrophytes & - & - & 3 & 1 & 24 & 9 & 69 & 25 \\
\hline $\begin{array}{l}\text { filamentous } \\
\text { green algae }\end{array}$ & - & - & 2 & 0.5 & 4 & 1 & 5 & 2 \\
\hline fish & 30 & 3 & 1 & 0.1 & 1 & 0.1 & 1 & 0.1 \\
\hline Total & 91.5 & 34.1 & 66 & 39.5 & 59 & 33.2 & 97.5 & 36.9 \\
\hline
\end{tabular}


Table 4. Data on the fish stock in Lake Zwemlust in October-December 1989 . The $0^{+}$rudd were discriminated according to their length frequency into two cohorts.

\begin{tabular}{|c|c|c|c|c|c|c|c|}
\hline $\begin{array}{l}\text { Species } \\
\text { and age }\end{array}$ & $\begin{array}{l}\text { Bodyweight } \\
\text { mean } \\
\text { (g) }\end{array}$ & $\begin{array}{l}\text { Forlength } \\
\text { mean } \\
(\mathrm{cm})\end{array}$ & $\begin{array}{l}\text { Abundance } \\
\text { (individuals) }\end{array}$ & $\begin{array}{l}95 \%- \\
\text { confidence } \\
\text { interval }\end{array}$ & $\begin{array}{l}\text { Total } \\
\text { catch } \\
\text { unmarked }\end{array}$ & $\begin{array}{l}\text { Biomass } \\
\left(\mathrm{kg} \mathrm{ha}^{-1}\right)\end{array}$ & $\begin{array}{l}\text { Relative } \\
\text { condition }\end{array}$ \\
\hline Rudd $0^{+}$ & 0.55 & 3.7 & 5100 & & 302 & 1.8 & 0.88 \\
\hline Rudd $0^{+}$ & 1.97 & 5.5 & 79200 & & 4687 & 103.0 & 0.95 \\
\hline Rudd $1^{+}$ & 33.2 & 12.8 & $?$ & & 20 & & 1.00 \\
\hline Rudd $>1^{+}$ & 305.0 & 24.1 & $?$ & & 13 & & 1.16 \\
\hline Pike $>0^{+}$ & 363.8 & & 30 & 18 & 20 & 7.4 & 0.85 \\
\hline
\end{tabular}

L. peregra inhabiting E. nuttallii were reduced from 113 ind. $\mathrm{m}^{-2}$ to 10 ind. $\mathrm{m}^{-2}$ thereafter in the swimming area. Densities of this snail on the bottom, remained constant at about 10 ind. $\mathrm{m}^{-2}$. Harvesting of the macrophytes had no discernible effect on the concentrations of nutrients and phytoplankton in the water.

Rudd spawned thrice in 1989: first in mid-May, the relative warm spring period, and at the end of June and late July. At the end of the growing season two cohorts of $0^{+}$rudd were recuited. The smaller cohort $(L=3.7 \mathrm{~cm}, W=0.55 \mathrm{~g})$ contained ca. 5100 fish, the larger cohort $(L=5.5 \mathrm{~cm}, \quad W=1.97 \mathrm{~g}) \quad c a .79200 \quad$ fish (Table 4). The total $0^{+}$biomass was estimated at $106 \mathrm{~kg} \mathrm{ha}^{-1}$. The condition factor of the $0^{+}$rudd, defined in Van Donk et al. (1989) was below normal (Table 4). In winter 88-89 densities of rudd of the year class 1988 were reduced markedly. During the growing season of 1989 these were caught only occasionally. Probably due to a further decline in condition, survival of the fish of the yearclass 1988 was very low such that their numbers could not be estimated (Table 4). At the end of the growing season the fish measured $10-15 \mathrm{~cm}$. Their condition and that of the older individuals was normal and above normal, respectively (Van Donk et al., 1989; Table 4).

In contrast to 1988 no pike fingerlings were stocked in 1989. In the sampling during the growth season and in autumn no $0^{+}$pike were encountered. The catch $\left(30\right.$ ind.) comprised $1^{+}$ and $2^{+}$individuals only (Table 4). The pike biomass decreased from 39.1 to $7.4 \mathrm{~kg} \mathrm{ha}^{-1}$. The average condition factor (Van Donk et al., 1989) was 0.85 (Table 4) indicating a poor condition. This was particularly so for the $2^{+}$pike; the condition of pike improved at the end of October, when the submerged vegetation degraded and the $0^{+}$rudd became more easily available as prey fish.

\section{Discussion}

Food-web manipulation of Lake $Z$ wemlust, i.e. removal of the planktivorous fish, did not affect the external nutrient load to the lake or the total concentrations of inorganic nutrients in the lake. The first pronounced effect observed was an increase in the biomass of large-sized zooplankton (Gulati, 1989), followed by an increase of submerged macrophytes. Both these increases were accompanied by drastic decrease in phytoplankton biomass. The lake's ecosystem changed from one dominated by cyanobacteria, rotifers and bream before manipulation, to one dominanted by submerged macrophytes, littoral grazers (zooplankton and macrofauna, especially snails) (Kornijow et al., 1990) and a pike/rudd fish community.

\section{Macrophytes-phytoplankton-nutrient interactions}

Shifts in abundance and composition of phytoplankton and zooplankton, after fish manipulation, have also been observed in several lakeenclosure experiments (e.g. McQueen \& Post, 1988). But the enormous increases in macrophyte abundance and shifts in distribution of $\mathrm{P}$ and $\mathrm{N}$ in the different compartments of lake's ecosystem 
have neither been predicted nor observed in shallow lake-enclosures. Most of these enclosure experiments were carried out for relatively short, uninterrupted periods, varying from weeks to a few months, and often excluded sediments.

The importance of submerged macrophytes in ecosystem functioning is often proportional to their biomass and productivity. The ecosystem effects of macrophytes, however, are not well known (Carpenter \& Lodge, 1986). Macrophytes may often accumulate large quantities of inorganic nutrients early in the growing season (Boyd, 1971). Nutrients stored during growth in early spring are utilized for growth later. So, macrophytes which start to grow early in the season have a competitive advantage over other macrophyte species and phytoplankton, which start growing relatively later.

Dense stands of macorphytes can cause deficiencies of nutrients in lake water (Boyd, 1971), like those observed in Lake Zwemlust. An important question about the role of macrophytes in lakes is the extent to which macrophyte beds act as a source or sink for a nutrient. Generally, macrophyte stands act as a sink for dissolved $\mathrm{N}$ (Howard-Williams, 1981). As regard dissolved P, the macrophytes usually may act as a sink in summer (Landers, 1982; Carpenter \& Lodge, 1986). In Lake Zwemlust in summers of both 1988 and 1989 dense stands of macrophytes acted as sink for $\mathrm{N}$ as well as $\mathrm{P}$, whereas before manipulation these nutrients accumulated chiefly in phytoplankton (Table 3). The very low concentrations of both nitrate and ammonium in summers 1988 and 1989 were caused most likely by denitrification and uptake of $\mathrm{N}$ by the macrophytes (Ozimek et al., 1990). Even though the $\mathrm{P}$ concentrations in 1989 were lower than in 1987 and 1988, these levels are still high enough to support dense populations of phytoplankton (Figs. 3 and 4). Bioassays performed with the natural phytoplankton population during these periods revealed a $\mathrm{N}$ limitation of growth-rate (Table 1).

The persistence of clear water in summers of 1988 was thus probably caused by macrophytes, unlike in 1987 when zooplankton grazing also in summer contributed chiefly to the high water clarity (Gulati, 1989). One drawback of the increase in macrophytes is the nuisance for swimmers; also the large scale development of snails, like $L$. peregra, was an undesirable development, since it led to complaints of swimmers' itch.

But the harvesting of only $3 \%$ of the total macrophyte biomass in Lake Zwemlust twice a year, exclusively in the swimming area, reduced the nuisance for swimmers and also did not adversely affect the water clarity.

\section{Zooplankton-phytoplankton-nutrient interactions}

The shift, observed in the composition and abundance of the phytoplankton community in favour of very small, edible species (Fig. 2), does not quite agree with the results of laboratory experiments or of lake-enclosures (e.g. Porter, 1977; Bergquist et al., 1985; Vanni, 1987). In these studies a shift toward a dominance of larger phytoplankton species after an increase in largesized daphnids was observed; the phytoplankters are often equiped with a gelatinous sheath or hard covering that presumably reduces their vulnerability to grazing. The published studies indicate that grazing of zooplankton on smaller species allows the inedible species to become abundant. Most of these findings are, however, based on only short-period experiments rather than longterm whole-lakes studies. In Lake Zwemlust, after food-web manipulation, phytoplankton species relatively resistant to zooplankton grazing (e.g. Colacium sp., Aphanizomenon flos-aquae and Volvox aureus), occurred only in low densities (Fig. 2). During long-term nutrients limitation, like in Lake Zwemlust, small-sized algae are likely to have a competitive advantage due to their favourable surface to volume ratio as regards nutrient assimilation (Reynolds, 1988). Similar observations have been made also in other wholelake experiments in The Netherlands (Meijer et al., 1989) and abroad (e.g. Leah et al., 1980; Reinertsen \& Olsen, 1984). From the enrichment bioassays and the grazing measurements we may conclude that after the food-web manipulation the 
growth of the phytoplankton is regulated by more than one factor, operating simultaneously or successively. Thus, zooplankton grazing in spring, nitrogen limitation caused by macrophytes and grazing prevented build-up in summer, and temperture and light in winter mainly controlled the phytoplankton growth. Furthermore, size-related selection pressures on the phytoplankton seem to have invariable conflicting effects: like smallsized algal taxa being favoured during nutrient limitation because of a high S/V ratio, but suppressed by size-selective zooplankton grazing (Lehman, 1988). Due to this, the large-sized inedible taxa were apparently not able to outcompete the small-sized and edible, but fast growing 'C-strategists' (Reynolds, 1988).

\section{Fish-zooplankton-macrophytes interactions}

A sustained reduction of planktivorous fish was considered essential in biomanipulation aimed at increasing water transparency (Shapiro \& Wright, 1984; Benndorf et al., 1988). For that propose the enhancement of pike populations can be a feasible tool in shallow waters (Grimm \& Backx, 1990). In Lake Zwemlust establishment of a strong pike population, maintaining a biomass of about $110 \mathrm{~kg} \mathrm{ha}^{-1}$, was one of the goals (Van Donk et al., 1989). This was, however, not realized during the 3-year study. In 1987 this was due to lack of sufficient aquatic vegetation and suitable forage fish but in 1988 and 1989 shortage of food also played a role. Very few of the rudd of the 1988 yearclass survived the winter and only a few older fishes were present (Table 4), thus prey fish were not available until mid-summer. Thereafter the large and dense fields of macrophytes, in which the $0^{+}$rudd foraged, made it difficult for the $1^{+}$and $2^{+}$pike to prey upon the $0^{+}$rudd. These pike apparently starved and resorted to cannibalism. Recruitment of a new yearclass did not occur, possibly because of the high $\mathrm{pH}$ (10.4) accompanying the explosive growth of submergent vegetation in April 1989.

Nonetheless, despite low pike biomass and abundance of juvenile rudd, phytoplankton biomass remained low. This latter may be due to competitive exclusion caused by macrophytes in summer; also the absence of planktivorous fish is important in the spring. Whether phytoplankton blooms will occur or not in near future probably depends on the survival of the $0^{+}$rudd, which unlike larger individuals that exploit macrophytes as food (Prejs, 1984), feeds primarily on zooplankton. Even though the condition of $0^{+}$ rudd was below average (Table 4) in 1989, it was better than in 1988. Consequently recruitment to the next spring may be such that zooplankton will be overpredated in early 1990 when macrophytes are still temperature/light limited and cannot play a major role in nutrient uptake.

\section{Conclusions}

In Lake Zwemlust food-web manipulation markedly improved the watertransparency during three consecutive years. The lake, nevertheless, still exhibits instability at the different trophic levels: 1) predatory fish, which might control the planktivorous fish, have neither become dominant nor yet stabilized; 2) due to the high and continual nutrient loading via seepage from the River Vecht macrophytes have, and are likely to exhibit such recurrent luxuriant growth that their mechanical control is necessary. The whole-lake manipulation followed by monitoring of different parameters as well as the laboratory experiments provided insights into community processes, nutrient competition and interactions, especially regarding macrophytes. We believe that such an insight would not have been possible from studies solely in lake-enclosures. The three-year success with regard to the lake's management is no guarantee for a long-term achievement in this small lake, let alone in larger lakes. In this regard we plan to continue the studies in Lake $Z$ wemlust for several more years, and have recently started a similar study in Lake Breukeleveen, a lake two order of magnitude larger in area than lake $\mathrm{Z}$ wemlust (Van Donk et al., 1990b).

Important questions, underlying the use of food-web manipulation as a restoration tech- 
nique, are the long-term effectiveness of this measure and the possibility for application on a larger scale.

\section{Acknowledgements}

We thank F. Jacques and his co-workers for carrying out the fishery operations, J. P. Kniese, J. van de Hout, P. G. M. Heuts, K. Siewertsen and W. De Kloet for their work in the field and laboratory, A. Stevens and I. Breedijk for typing the manuscript, and E. J. Lerou for making the drawings. We are most grateful to B. A. Faafeng, M.-L. Meijer and two referees for their valuable comments on the manuscript.

\section{References}

Benndorf, J., H. Schultz, A. Benndorf, R. Unger, E. Penz, H. Kneschke, K. Kossatz, R. Dumke, U. Hornig, R. Knispe \& S. Reichel, 1988. Food Web manipulation by enhancement of piscivorous fish stocks: long-term effects in the hypertrophic Bautzen Reservoir. Limnologica 19: 97-110.

Bergquist, A. M., S. R. Carpenter \& J. C. Latina, 1985. Shifts in phytoplankton size, structure and community composition during grazing by contrasting zooplankton assemblages. Limnol. Oceanogr. 30: 1037-1046.

Boyd, C. E., 1971. The limnological role of aquatic macrophytes and their relationship to reservoir management. Res. Fish. Limnol. 8: 153-166.

Carpenter, S. R. \& J. F. Kitchell, 1988. Consumer control of lake productivity. Bioscience 38: 764-769.

Carpenter, S. R. \& D. M. Lodge, 1986. Effects of submerged macrophytes on ecosystem processes. Aquat. Bot. 26: 341-370.

Edmondson, W. T. \& S. E. B. Abella, 1988. Unplanned biomanipulation in Lake Washington. Limnologica 19: 73-79.

Frost, T. M., D. L. DeAngelis, S. M. Bartell, D. J. Hall \& S. H. Hurlbert, 1988. Scale in the design and interpretation of aquatic community research. In S. R. Carpenter (ed.), Complex interactions in lake communities. SpringerVerlag: 229-261.

Golterman, H. L., 1969. Methods for chemical analysis of freshwaters. IBP Handbook 8, Blackwell Scientific Publications, Oxford, $166 \mathrm{pp}$.

Grimm, M. P., 1989. Northern pike (Esox lucius L.) and aquatic vegetation, tools in the management of fisheries and water quality in shallow waters. Hydrobiol. Bull. 23: 59-65.

Grimm, M. P. \& J. J. G. M. Backx, 1990. The restoration of shallow eutrophic lakes and the role of northern pike, aquatic vegetation and nutrient concentration. Hydrobiologia 200/201: 557-566.

Guillard, R. R. L., 1975. Culture of phytoplankton for feeding marine invertebrates. In: W. L. Smith \& M. H. Chanley, (Edts.), Culture of marine invertebrate animals. Plenum Press, New York: 26-60.

Gulati, R. D., 1989. Structure and feeding activity of zooplankton community in Lake Zwemlust, in the two years after biomanipulation. Hydrobiol. Bull. 23: 35-49.

Gulati, R. D. \& E. Van Donk, 1989. Biomanipulation in the Netherlands: applications in fresh water ecosystems and estuarine water - an introduction. Hydrobiol. Bull. 23: $1-5$.

Gulati, R. D., K. Siewertsen \& G. Postma, 1982. The zooplankton: its community structure, food and feeding, and role in the ecosystem of Lake Vechten. Hydrobiologia 95: $127-163$.

Hosper, S. H., 1989. Biomanipulation, new perspective for restoring shallow, eutrophic lakes in The Netherlands. Hydrobiol. Bull. 23: 11-19.

Hosper, S. H. \& M.-L. Meijer, 1986. Control of phosphorus loading and flushing as restoration methods for Lake Veluwe, The Netherlands. Hydrobiol. Bull. 20: 183-194.

Howard-Williams, C., 1981. Studies on the ability of a Potamogeton pectinatus community to remove dissolved nitrogen and phosphorus compounds from water. J. appl. Ecol. 18: 619-637.

Hurlbert, S. M., 1984. Pseudoreplication and the design of ecological field experiments. Ecol. Monogr. 54: 187-211.

Kornijow, R., R. D. Gulati \& E. Van Donk, 1990. Hydrophyte-macroinvertebrate interactions in Zwemlust, a lake undergoing biomanipulation. Hydrobiologia 200/201: 467-474.

Lammens, E. H. R. R., 1989. Causes and consequences of the success of bream in Dutch eutrophic lakes. Hydrobiol. Bull 23: $11-19$.

Landers, D. H., 1982. Effects of naturally senescing aquatic macrophytes on nutrient chemistry and chlorophyll $a$ of surrounding waters. Limnol. Oceanogr. 27: 428-439.

Leah, R. T., B. Moss \& D. E. Forrest, 1980. The role of predation in causing major changes in the limnology of a hyper-eutrophic lake. Int. Revue ges. Hydrobiol. 65: 223-247.

Lehman, J. T., 1988. Selective herbivory and its role in the evolution of phytoplankton growth strategies. In C. D. Sandgren (ed.), Growth and reproductive strategies of freshwater phytoplankton. Cambridge University Press: 369-388.

McQueen, D. J. \& J. R. Post, 1988. Limnocorral studies of cascading trophic interactions. Verh. int. Ver. Limnol. 23: 739-748.

Meijer, M.-L., A. J. P. Raat and R. W. Doef, 1989. Restoration by biomanipulation of the Dutch shallow, eutrophic lake Bleiswijkse Zoom: first results. Hydrobiol. Bull. 23: $49-59$ 
O’Neill, R. V., D. L. DeAngelis, J. B. Waide \& T. F. H. Allen, 1986. A hierarchical concept of ecosystems. Princeton: Princeton University Press.

Ozimek, T., R. D. Gulati \& E. Van Donk, 1990. Can macrophytes be useful in biomanipulation of lakes? The lake Zwemlust example. Hydrobiologia 200/201: 399-407.

Porter, A., 1977. The plant-animal interface in fresh water ecosystems. Am. Sci. 65: 159-170.

Prejs, A., 1984. Herbivory by temperate freshwater fishes and its consequences. Envir. Biol. Fishes 10: 281-296.

Reinertsen, H. \& Y. Olsen, 1984. Effects of fish elimination on the phytoplankton community of a eutrophic lake. Verh. int. Ver. Limnol. 22: 649-657.

Reynolds, C. S, 1988. Functional morphology of the adaptive strategies of freshwater phytoplankton. In: Sandgren, C. D. (Ed.), Growth and reproductive strategies of freshwater phytoplankton. Cambridge University Press: $388-434$.

Shapiro, J. \& D. J. Wright, 1984. Lake restoration by biomanipulation: Round Lake, Minnesota, the first two years. Freshwat. Biol. 14: 371-383.

Sokal, R. R. \& F. J. Rohlf, 1969. Biometry. The principles and practice of statistics in biological research. Freeman, W. M. \& Comp., San Francisco.

Van Donk, E. \& C. Collé, 1988. Schistosome dermatitis, a possible complication of food-web manipulation in swimming waters (in Dutch; English summary). $\mathrm{H}_{2} \mathrm{O} 24$ : 696-699.
Van Donk, E., R. D. Gulati \& M. P. Grimm, 1989. Food-web manipulation in Lake Zwemlust: positive and negative effects during the first two years. Hydrobiol. Bull. 23: $19-34$.

Van Donk, E., R. D. Gulati \& M. P. Grimm, 1990a. Restoration in a small hypertrophic lake: first-year results. Hydrobiologia 191: 285-296.

Van Donk, E., A. Veen \& J. Ringelberg, 1988. Natural community bioassays to determine the abiotic factors that control phytoplankton growth and succession. Freshwat. Biol. 20: 199-210.

Van Donk, E., M. P. Grimm, R. D. Gulati, P. G. M. Heuts, W. A. De Kloet \& E. Van Liere, 1990b. First attempt to apply whole-lake food-web manipulation on a large scale in the Netherlands. Hydrobiologia 200/201: 291-301.

Van Liere, E., 1986. Loosdrecht lakes, origin, eutrophication, restoration and research programma. Hydrobiol. Bull. 20: 9-15.

Van Liere, E., L. Van Ballegooijen, W. A. De Kloet, K. Siewertsen, P. Kouwenhoven \& T. Aldenberg, 1986. Primary production in the various parts of the Loosdrecht lakes. Hydrobiol. Bull. 20: 77-85.

Vanni, M. J., 1987. Effects of nutrients and zooplankton size on the structure of a phytoplankton community. Ecology 68: 624-635.

Winberg, C. G. et al., 1971. Symbols, units and converison factors of freshwater productivity. IBP. London, $23 \mathrm{pp}$. 